\title{
The Jurassic-Cretaceous boundary: An age-old correlative enigma
}

\author{
Department of Earth Sciences, University of Bristol, Queens Road, Bristol BS8, United Kingdom. E-mail: newaberdon@tiscali.co.uk
}

\begin{abstract}
The Jurassic-Cretaceous boundary interval has been problematic since the start of stratigraphic study. This is reflected in different stage names being employed in Boreal and Tethyan realms below and above the putative boundary. Despite attempts at homogenisation where stage terminology is concerned, correlative precision over long distances at or close to a boundary has not yet been achieved. But the new Berriasian/ $J-K$ boundary working-group of the Cretaceous Subcommission is now attempting to remedy this situation.
\end{abstract}

\section{Introduction}

The Berriasian is not a "marine stage", as one sees written sometimes: it is the one and only name for the initial stage of the Cretaceous System, and the first "age" of the period. It needs to be, but is not yet, definable in a GSSP. That datum must be readily correlatable, traceable as much as possible around the world-utility being the major consideration. But this J-K boundary interval is correlatively one of the most difficult, and it is not chance that it is one of the very last GSSP tasks to be tackled by the ICS and its subcommissions. Removal by mid-Cretaceous erosion over large regions, faunal separation into boreal and tethyan 'realms', prolonged isolation of individual basins within these, and the prevalence of nonmarine sequences across the boundary have combined to afford a correlative enigma for geologists since the start of stratigraphical study. Cracking this 'nut' in a coherent and lasting fashion is one of the larger challenges for the ICS.

The story of attempts to place the Jurassic-Cretaceous boundary was for several generations one of placing an upper limit to Jurassic formations. Once these had been well defined in England by native workers, notably Fitton in 1827, Brongniart (1829) erected stages (Portlandian, Purbeckian) - though these were in reality only lithostratigraphic entities. Whereas, D'Orbigny founded stages on index fossils, retaining Portlandian and using the last ammonite, Sowerby's Ammonites giganteus, to define the top of it and the Jurassic (as did Oppel for his "Tithonian"), relegating Brongniart's Purbeckian to the Neocomian. For Alcide d'Orbigny (1842-51) and many who came afterwards that formational junction was the J-K boundary. Recognition of the diachronous nature of the largely non-marine Purbeck formation (of Portlandian to Valanginian age) in southern England, the type area, northern France and the Jura came much later (Allen \& Wimbledon, 1991). The name Neocomian, named loosely to cover the marine Purbeckian of Alps, had already been coined prior to d'Orbigny's fundamental work: though Berriasian (= infraValanginian) did not yet exist, it came forty years after. Later attempts to fix a Neocomian base in the marine successions of the western Mediterannean have brought suggested ammonite bases that have fluctuated up and down, or remained vague. What were later recognised as Tithonian faunas were used to define the Berriasian: long-ranging species which persisted into the Berriasian were seen as typically
Tithonian by Kilian, and Toucas even placed the stage in the Jurassic (Arkell, 1956). For Kilian (1907-10), the base of the Berriasian was finally the Fauriella boissieri zone, and for Mazenot (1939) the horizons of Kilian became the three subzones of Berriasella grandis, $B$. boissieri s.s. and Kilianella aff. pexiptycha. It can be said that the Berriasian basal biozone, the jacobi/grandis interval, is still somewhat lacking definition, and the problem of taxonomic diversity and low fossil numbers that beset the uppermost Tithonian and the lower Berriasian in the area remain an impediment. But only these lower levels have ever seriously been discussed as the level to recognise a Berriasian base.

Subsequently, in 1963 and 1973, two colloquia (Lyon and Lyon/ Neuchatel) were to vote and adopt the ammonite assemblages of the Pseudosubplanites grandis and Berriasella jacobi subzones as indicators for the base of the Berriasian. These decisions, one has to say, were made by gatherings of specialists who predominantly worked in the western Mediterranean, and decisions were founded on consideration of Tethyan ammonites only. But at the time there was little else to consider. Hoedemaeker (1987) considered that the conference decisions were unlikely to be implemented in practice, and suggested the base of the Subthurmannia subalpina subzone as a more definable option. Nevertheless, the overwhelming majority of authors have continued to use the jacobi subzone (base of grandis zone) or grandis subzone in defining a stage base, or a vaguer grandis or jacobi/grandis zone. Though it has to said that on the basis of ammonite faunas themselves, these subzones are still not really divisable. That fact notwithstanding, even in the very large part of the world outside Tethys, work trying to fix a boundary has concentrated on correlating with a jacobi/grandis zone.

\section{Todays' world}

The provincialism and facies limitations affecting faunal and floral elements - ammonites, and later-studied buchiids, calpionellids and nannofossils - has for generations prevented substantial progress with long-range correlation in the Jurassic-Cretaceous interval. Even consistent regional results have not been applicable in all areas, in all facies, or even most, let alone in all parts of a single so-called "realm". Geologists' inability to correlate ammonites with any great certainty even within a realm (e.g., the key Greenland-Britain-Russia triangle) has led to circularity of discussion and what have been quite unnatural schemes of zonal comparison (and stage nomenclature), that have tended to conceal the lack of actual correlation at specific level (diagrams showing what were, in truth, surmised matches) and the prevalence of inferable non-sequence

Sometimes odd specimens of an ammonite species, or even genus, have been clutched at to derive the much hoped-for tie point and overcome the barriers imposed by endemic faunas. The contribution of Sey and Kalacheva (1997) on the correlation of the Caucasus, Crimea, Russian platform and western Tethys was a great step forward. Their results gave solid connections between at least some tethyan and boreal areas, for instance showing equivalence at the Dalmasiceras dalmasi and Riasanites zonal levels (Figure 1); and 


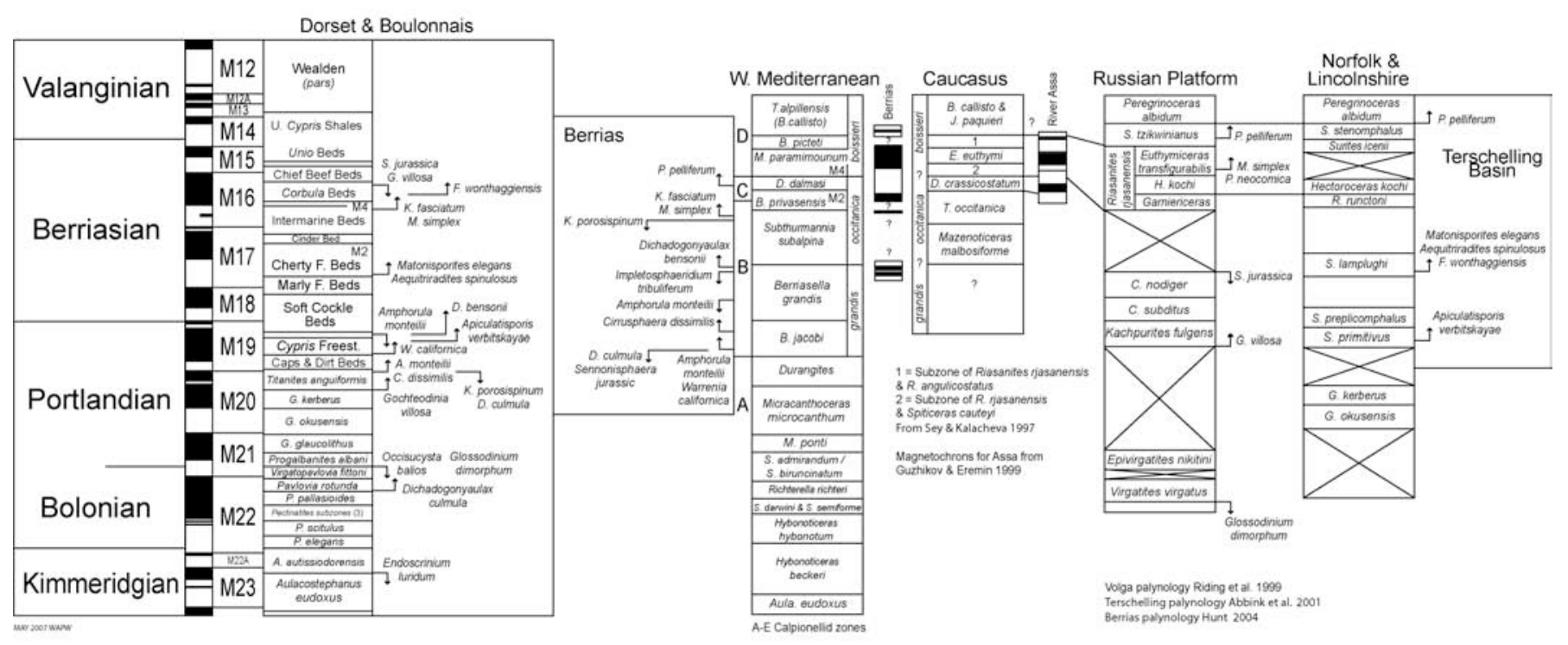

Figure 1 A correlation of the type Kimmeridge, Portland and Purbeck (M22-M13) formations of England and northern France with the North Sea Basin, Russian Platform, Caucasus and Western Mediterranean, using ammonites, palynomorphs and magnetostratigraphy.

key magnetostratigraphic potential came with the work of Guzhikov and Eremin (1999).

We are now in a different stratigraphic world to that at the time of the earlier conferences: more of the world is better known and we have at our disposal a much better suite of stratigraphic indicators, fossil and otherwise, than were previously available. We are no longer constrained by one or two groups of fossils, and sometimes a very limited number of taxa within these. In the 1970 s, no agreement was possible even on the equivalence of the Portlandian, Volgian and Tithonian, nor of where precisely a J-K boundary might sit in areas outside the western Mediterranean. On magnetostratigraphic and palynological grounds, the Portlandian-Berriasian boundary level has now been localised in western Europe, and the L.-M. Volgian is now seen to span the Bolonian (=Upper Kimmeridgian) and Portlandian (Tithonian) and it is clear that the Upper Volgian has a latest Portlandian, perhaps, but mostly Berriasian age ( Figure 1).

Wider and effective use of a jacobi subzone, following the 1973 colloquium decision, or any other alternative used in a global sense, still requires considerable thought on the matter of multidisciplinary correlation. This maximisation of correlative precision demands work on useful surrogate indicators or proxies, alternatives to the ammonites - and indeed a whole suite of alternative microfossil indicators, geochemical and palaeomagnetic techniques can now be brought to bear.

Berriasian correlation has moved on considerably in the last thirty years, with significant work carried out in several regions outside the western Mediterranean: notably in Ukraine, the Caucasus, Siberia and the Russian Far-East, as well as China and Japan. Substantial progress has been made in identifying Tethyan ammonites in Russian sequences, and also in correlating European Russia and Britain, and in those regions from Iberia to Poland with largely nonmarine facies. Correlation between non-marine and marine, once totally conjectural, is now possible in a number of geographic areas, based on integration of palynomorphs, shelly fossils and magnetostratigraphy. And latterly, somewhat sidelining macrofossils, considerable advances in palynological studies have transformed the situation of impasse. In the last three decades, in particular, work by Hunt, Herngreen, Abbink (Abbink et al., 2001) and Monteil, working in part on the preliminary assays by Davey, Norris and Dorhofer etc, have revealed the possibility, at last, of substantial Boreal: Tethyan and marine: non-marine correlation.

\section{Tethys and calpionellids}

In certain Tethyan areas lacking ammonites, calpionellids have become a key tool in biostratigraphy, such as in the pelagic limestone sequences of Italy and middle Europe. But, as to the direct equivalence of ammonite biozones and those founded on calpionellids, the situation is not entirely clear near a putative J-K boundary. Zonations of Allemann and Remane (Allemann et al., 1971; Remane, 1971, Remane et al., 1986 ) have been elaborated (Grun \& Blau 1997, etc), and C. alpina has been used to indicate the lower part of calpionellid zone B ("lower-middle Berriasian"), though it has a range well below that biozone, and C. elliptica the upper part. A more restricted interval, an acme of the long-ranging Calpionella alpina, not the zone, has latterly been used as an indicator of a "J-K boundary" (Houša et al., 1999). One measure of the question marks over calpionellid correlation and the correlation of calpionellid zone $\mathrm{B}$ to the base of the Berriasian, is that in Spain, where calpionellids occur with ammonites, the base of the $B$. jacobi biozone occurs not in the nominal zone of $C$. alpina (biozone B), but in the A2 zone (Tavera et al., 1994). Similarly the base of B has previously been placed in M19r (at Bosso) and high in M19n (e.g. Xausa).

M18n was formerly the only 'normal' magnetozone identified in calpionellid zone $\mathrm{B}$, then providing an approximation to a jacobi/grandis zone (Ogg et al., 1991: Channell \& Grandesso, 1987). Initially numbering of chrons relied somewhat on Galbrun's original numbering at Berrias (Galbrun et al., 1986); as already mentioned a problematic section (and type area) to have as a standard. Given the nature of the sediments and apparent breaks in the grandis, subalpina and privasensis intervals there, it is perhaps not surprising that it is difficult to match its magnetostratigraphy conclusively with that in thicker and presumed more complete sequences, such as at Durlston or Bosso. It has also been suggested for some time that the base of the Berriasian could be equated to magnetic chron M18 using the jacobi subzone (Bralower et al., 1990), or the base of a grandis subzone (Ogg et al., 1991; Lowrie \& Channell, 1983), and authors previously gave such assignments. Using the base of the grandis zone/jacobi subzone, however, gives an alternative M19n assignment. Such has been the usage recently for J-K boundary placement in Slovakia and Poland (Michalik et al., 1990; Houša et al., 1999; Grabowski, 2000, 2006). 


\section{Magnetostratigraphy and palynology combined}

Galbrun's lowest recorded magnetochron at Berrias, in the grandis subzone, is perhaps assignable to M18r, which gives at least an approximation there for the position of the base of the underlying jacobi subzone in the magnetic scale. Perhaps the base of jacobi falls in M18n, which would accord with the Hard Cockle Beds of Dorset. The base of jacobi subzone in southern France has been taken to be coincident with the base of the calpionellid biozone B. However, at Bosso (Lowrie \& Channell, 1982), the base of biozone B was formerly recorded within M19r.

The thick sequences of the Dorset Portland and Purbeck, the original latest Jurassic standards, have yielded a good magnetostratigraphic record (Portland formations M21n-M20n; and Purbeck Formation M20n-M13r), which when added to the Kimmeridge ClayPortland sequence of the northern French coast (M22r-M20n) pro-
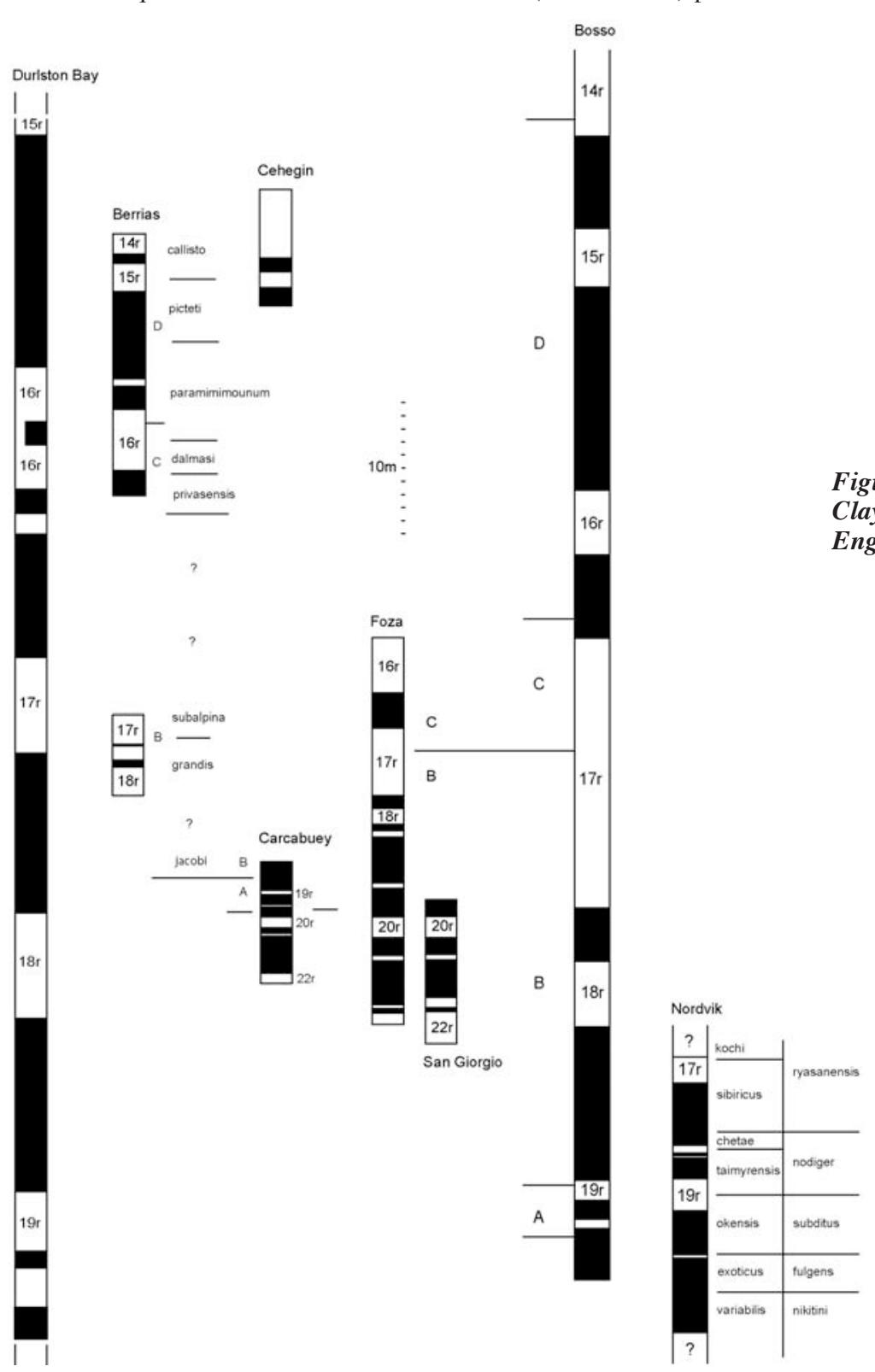

Figure 2 Magnetostratigraphy of selected Boreal and Tethyan sequences: Durlston pars (U.K.), Berrias (France), Cehegin and Carcabuey (Spain), Fozo, San Giorgio and Bosso (Italy), and Nordvik (Russia).

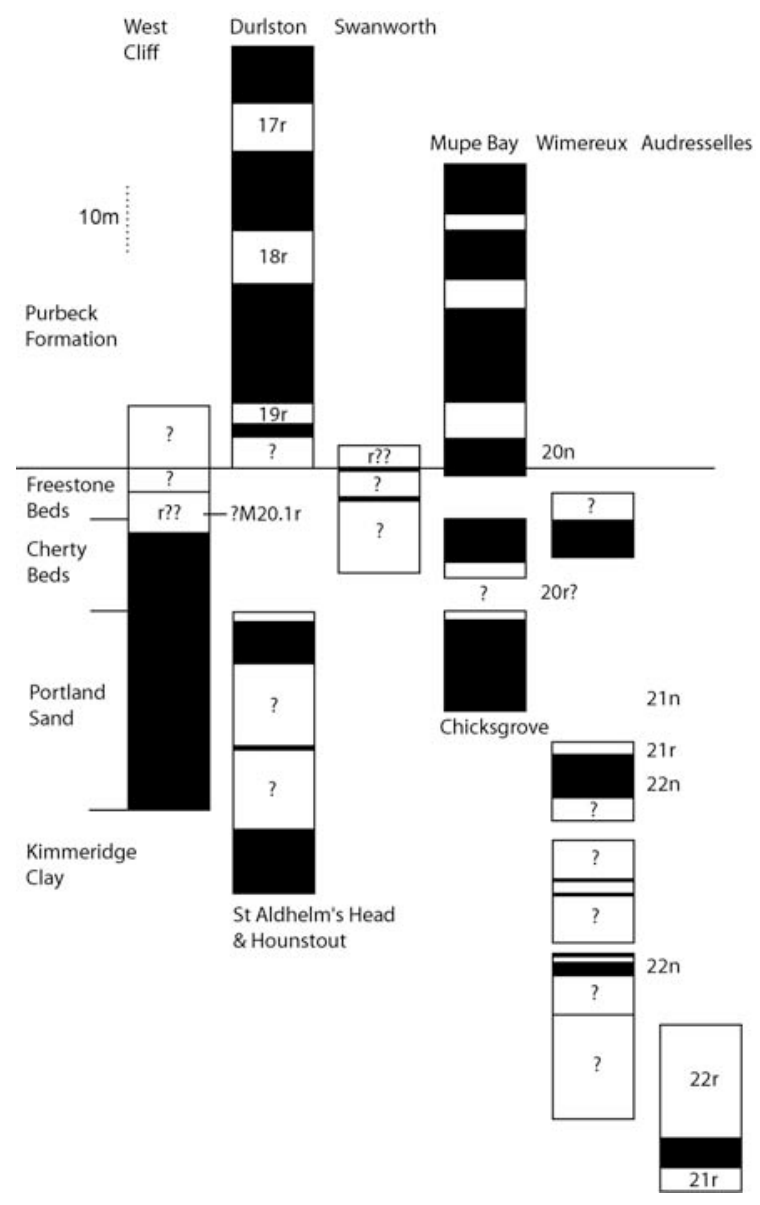

Figure 3 Magnetostratigraphy of the type upper Kimmeridge Clay, Portland and lower Purbeck formations in southern England and northern France.

vide a useful comparative standard against which thinner Boreal and deeper-water, and more often thinner, Tethyan sections may be compared (Figure 1). Chron comparisons are clear with the pelagic or hemipelagic sequences, such as Bosso or Brodno, for instance (Figure 2).

The marine/non-marine succession in Dorset (and the Boulonnais), the original d'Orbigny type area, has been sampled for magnetostratigraphy with increasing intensity since 1987 (Figure 3). Palynocysts in bed 148 at Berrias (grandis subzone) are the same as those in the Hard Cockle beds of Durlston Bay, assigned there to magnetochron M19n (Figure 4). Other species immediately beneath the lowest 'normal' chron recorded at Berrias (Galbrun et al., 1986), putatively M18 and in the grandis subzone, correlate with the Cypris freestones of Dorset (lower M19n). Palynocysts in bed 149 (subalpina subzone) at Berrias (no magnetochron assigned) correlate with the same in the Scallop bed at Durlston in M16n. Hunt postulated (2004) a large hiatus between bed 146 and bed 149 at Berrias: all within calpionellid zone $\mathrm{B}$, and consistent with sedimentary evidence of nonsequence, visible from the top of the Tithonique to the privasensis subzone.

The constraining biostratigraphic framework for matching the Durlston and Berrias magnetochrons had been reinforced previously by use of ammonites and ostracods. One Cypridea assemblage (fauna M4 of Detraz \& Mojon, 1989), with a combination of species long only known at the top of the Dorset Intermarine beds, was located in the Jura, in beds (Fmn de Pierre Chatel) sandwiched between units 
with privasensis and paramimounum ammonites. The dalmasi-paramimounum subzones straddle a reversed magnetochron at Berrias, and this reversed chron there and the one which encompasses most of the Intermarine beds at Durlston have, independently, been assigned to M16r. However, dinocysts from beds just above the ostracod-bearing level at Durlston (Scallop bed) match ostracods from the subalpina subzone at Berrias (oooo-Figure 4). The dinocysts (pppp-Figure 4) in the Cypris Freestones (M19n) equate to the same species in the grandis zone below the 'normal' chron found by Galbrun, which may raise questions about the numbering of that chron at Berrias.

As to elsewhere in Tethys (Figure 2), good magnetostratigraphic results from sequences in Spain and Italy match well with one another. The latter from sections with good calpionellids successions, but no ammonites (or palynology), and the former with ammonites and calpionellids, but poor palynology. Thicker sequences such as Bosso in Italy provide a solid magnetostratigraphy and calpionellid-based biostratigraphy, as do the more condensed pelagic successions, like Brodno in middle Europe.

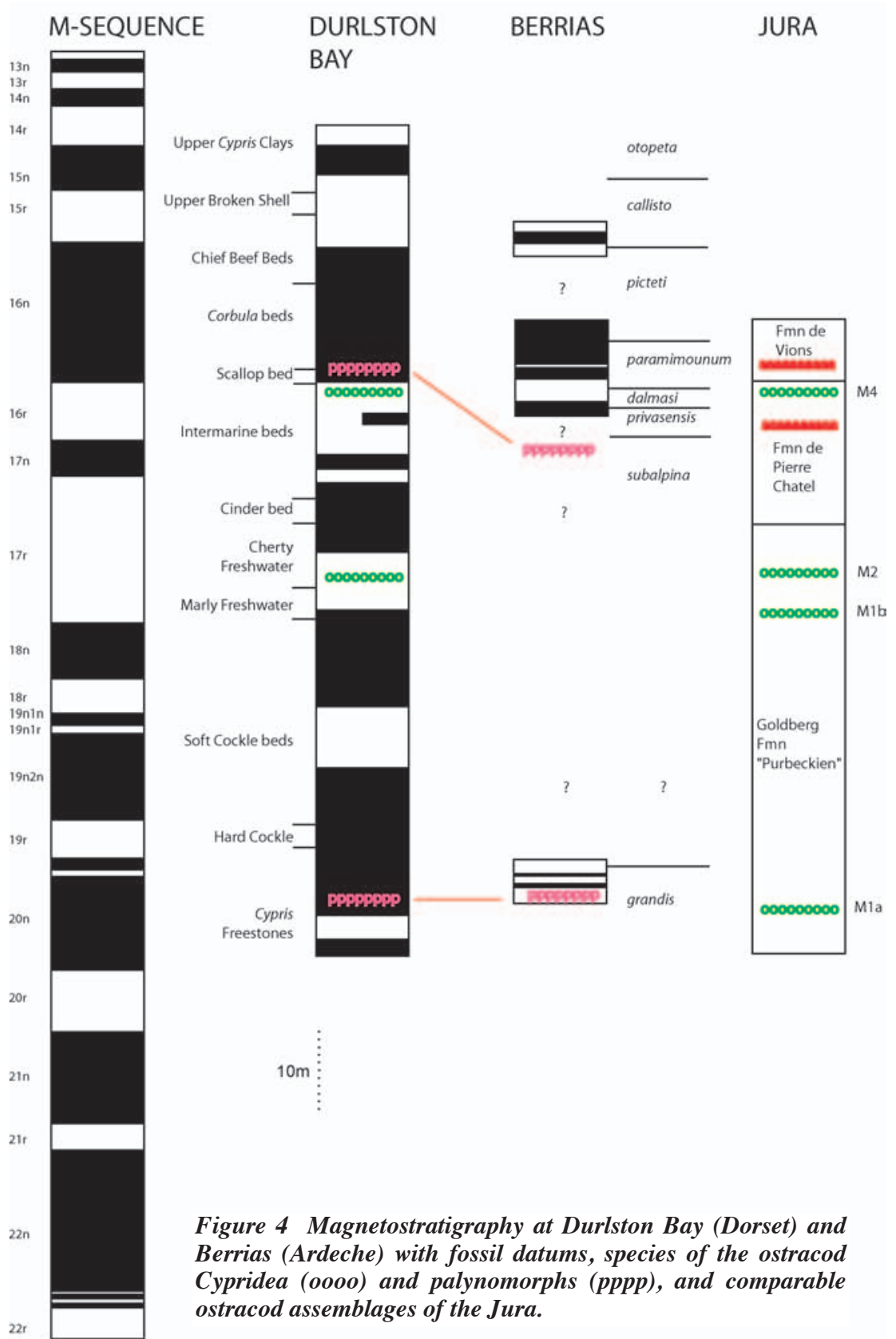

\section{Boreal contradictions}

With J-K correlation in the so-called boreal realm, some decidedly solid problems remain. In the main this is because of the past dependence on ammonites. Post-Kimmeridge Clay times, widespread pavloviid ammonites gave way to local virgatitids, dorsoplanitids and their craspeditid offshoots. This post-Pavlovia interval is still for the most part marked by mismatching faunas up to and beyond the top of the Jurassic, until assemblages with Chaetites, Praetollia and then more ubiquitous Hecteroceras appear, but by then we are well into the upper Berriasian (Figure 5).

The comparability of the British/French and Greenland sequences at the $\mathrm{J} / \mathrm{K}$ boundary with the proximal, sediment-starved clastic deposits of Russia is still not resolved. After the Epipallasiceras of Greenland (faunas 40-42) and those in the early Portlandian Progalbanites [Zaraiskites] albani zone of England and France, some comparability of faunas to okusensis zone times can be seen with eastern Greenland, with later vogulicus zone Crendonites also perhaps being equateable with English forms (Wimbledon, 1983). But, with Russia the only possibilities for correlation are seemingly Epivirgatites of the nikitini zone. Though this seems far too early, if the approximately basal Berriasian Kachpurites fulgens zone is indeed conformable on the nikitini zone on the Volga: sediments suggest otherwise. The traditional correlation by Russian workers (Gerasimov and Michailov, 1966, etc.) was of the English albani zone and the Russian platform Zaraiskites zarajskensis subzone, of Crendonites gorei with a Virgatites virgatus zone, and a zone of "Titanites giganteus" with Epivirgatites nikitini: the last based on the long-held view that Lomonossovella and the so-called "Kerberites" in Russia could be matched with Portland Stone ammonites (Arkell, 1935, 1953: Casey, 1973). But with revision of the latest Jurassic (-earliest Cretaceous) ammonites faunas of Britain and France, greater faunal complexity and an enlarged zone scheme resulted (Wimbledon and Cope, 1978; Wimbledon, 1983). Plus the conclusion that no Portland Stone equivalents could be identified at Moscow or on the Volga, and that the "Epivirgatites", Epipallasiceras and pavloviids of the albani zone (the lowest Portlandian) were, if anywhere, matched with the nikitini zone. It seemed impossible to accommodate the remaining four ammonite zones of the Portland Sand and Portland Stone formations, except between the nikitini and the fulgens zones. But this issue of internal boreal correlation, raised at the Erlangen symposium, remains: how is it possible to correlate all or even a substantial amount of the Portlandian-early Berriasian with the Volgian of Russia, if $70 \mathrm{~m}$ of Portland beds is being equated with solely the nikitini biozone (30-40 $\mathrm{cm}$ at Gorodishche and Kashpir and 50 $\mathrm{cm}$ at Moscow). The scale of any break (none is accepted by Russian workers) between the nikitini and fulgens zones remains contentious. The discrediting of a Paracraspedites oppressus zone in Britain (as not a true zone, but a conflation of species from perhaps three separate biozones) has raised doubts about there being any representation of the four southern English Portlandian ammonite zones (glaucolithus to anguiformis) and an "oppressus zone" in the type Volgian. The quite separate (later) sequences in eastern England with Subcraspedites primitivus, and then $S$. preplicomphalus are assumed (following Casey, 1973) to be equivalent to the fulgens to nodiger interval of the Russian plat- 


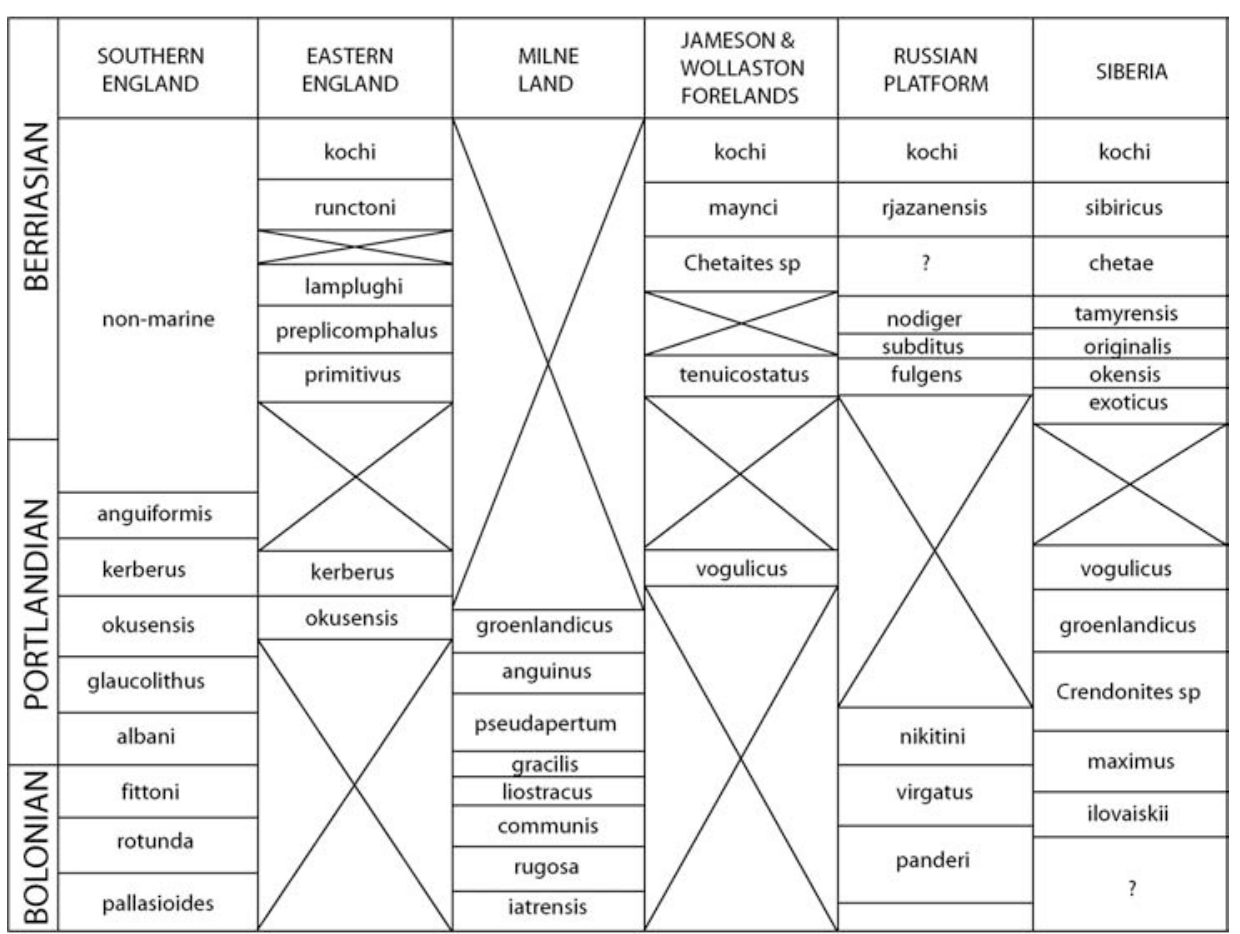

Figure 5 Approximate and disjunct correlations of the ammonite biozonations of the 'boreal' regions.

form, but they sit above a considerable hiatus and are marked internally (like biozones above) by phosphatic pebble units and erosive bases (Figure 5).

But the maintainence (Zakharov et al., 2006) of a "Paracraspedites" fauna to bridge this correlative abyss between east and west Europe and north Atlantic, matching "Paracraspedites" (one fauna of the Russian Platform nikitini biozone) and a zone of "P. oppressus" in England is an issue. As is the identification of Boreal ammonites in the fittoni and albani biozones of Dorset, which is seemingly the only level where species similar to those of Russia, distinctive virgatotome and polygyrate ribbed forms, commonly occur. It is difficult to see a match for these anywhere on the Russian platform, except in the nikitini zone (or lower). And in this conclusion, tentative ammonite correlations are supported by palynology, for the last appearance of the dinocyst Glossodinium dimorphum, which lies at the top of the Virgatopavlovia fittoni zone in Dorset, has latterly been recorded in the virgatus zone on the Volga (Riding et al., 1999), with Gochteodinia villosa, a Portland Freestone dinocyst, occurring in the Kachpurites fulgens zone and the miospore Apiculatisporis verbitskayae in the lower Purbeck and Subcraspedites preplicomphalus of the north Sea (?=Craspedites nodiger zone of Russia) (Figure 1).

The recent identification of Subcraspedites sowerbyi also in the Epivirgatites nikitini zone on the Volga is a fascinating record. That species in eastern England has been described only from beds (the $S$. preplicomphalus zone: Casey, 1973) which have been consistently correlated with the Craspedites nodiger zone. But its use (Zakharov et al., 2006) to suggest correlation of this nikitini zone with the preplicomphalus zone would mean that the nikitini zone would then have horizons equivalent to perhaps 5-6 ammonite biozones as defined in England.

Sey and Kalacheva's (1997) great step forward has been the foundation for refinement in recent times, and much new work on the ammonite correlations (e.g., Mitta, 2007; Zakharov et al., 2006). Mitta's finds of Dalmasiceras ex gr. djanelidzei and Malbosiceras nikolovi suggested to him the correlation of the Riasanites rjazanensis zone's lower boundary with that of the jacobi subzone in western Tethys. Further therefore, very radically, that the rjasanensis zone probably corresponds to the greater part of the
Berriasian, that is, to the interval between the lower grandis zone and the paramimounum subzone. A number of lines of evidence have led more consistently to acceptance that the rjasanensis zone correlates approximately with the paramimounum subzone, around magnetochron M16r, that is, at about the Praetollia (Runctonia) runctoni zone of eastern England and the North Sea basin (Figure 1).

The thicker, and maybe fuller, sequences of the Siberian upper Volgian raise new possibilities in J-K boundary correlation. Integration of the separate ammonite zonal schemes for Siberia and the Russian platform and external correlations are given new momentum by magnetostratigraphic results from Nordvik (Houša et al., 2007). This work provides the most complete record from Russia thus far, though, compared to western European magnetostratigraphic results (Figure 2), it appears to show condensation or reduced sedimentation at about the M18 level. It is also interesting that a $\mathrm{J}-\mathrm{K}$ boundary has been indicated in mid M19n in middle Europe (Houš a et al., 1999), but just above the base of a putative M18n at Nordvik (Houša et al., 2007: there is a mistake with chron numbering in their figure 2). The small reversed interval recorded as M20.1r at Nordvik (in exoticus ammonite zone=fulgens zone) is thus suggested as being the same as seen at the Cherty bed/Freestone member junction on Portland (T. anguiformis ammonite zone) and in Italy at Foza, San Giorgio and Bosso (?calpionellid zone A), perhaps M. microcanthum ammonite zone (Figure 3).

\section{A way forward}

On 5th July 2007, a new Berriasian Working Group (Subcommission on Cretaceous Stratigraphy) met for the first time in Bristol, UK. Attending members and correspondents unanimously decided to take a conservative line in its work to define the base of the stage and fix a GSSP. In trying to define a J-K boundary, it decided to maintain continuity with more recent historical understanding of the scope of the uppermost Jurassic and the lowest Cretaceous - thus to choose somewhere a GSSP, a Berriasian base, that is consistent with usage in recent decades: that is in or close to the base of the grandis (jacobi/grandis) zone. The primary task is correlation, and in coming months, in key regions, members of the WG will be collating information on correlatable markers (fossil or inorganic) within and close to that interval, markers that must have intra- and interregional utility.

The work only begins, but there are a number of datums which approximate, at least, to the base of the grandis zone, and provide potential proxies for its recognition and definition: for instance, the base of the Kachpurites fulgens ammonite zone, the FADs for Apiculatisporis verbitskaya, Amphorula monteilii and Warrenia californica, perhaps Gochteodinia villosa, and LADs for Dichadogonyaulax culmula and Sennonisphaera jurassica, the base of calpionellid zone B and so on. And it is also obvious that the precise data afforded by nannofossil lineages will play a key role. These can be constrained by magnetostratigraphy. The calibration of these markers and others is the task. It is to be hoped that, by use of truly multidisciplinary approaches, we can at last break the impasse that has existed for generations of workers, who founded their opinions on only one or two fossil groups. 


\section{Acknowledgement}

This is a contribution to IGCP 506, under the leadership of Prof. Sha Jingeng.

\section{References}

Abbink, O.A., Callomon, J.H., Riding, J.B., Williams, P.D.B., and Wolfard, A., 2001, Biostratigraphy of Jurassic-Cretaceous boundary strata in the Terschelling Basin, The Netherlands: Proceedings of the Yorkshire Geological Society 53, 275-302.

Allemann, F. et alia., 1971, Standard calpionellid zonation (Upper Tithonian -Valanginian) of the western Mediterranean Province. pp 1337-1340. In Farinacci, A. (Ed.) Proceedings of Second Planktonic Conference, Roma 1970.

Allen, P. and Wimbledon, W.A., 1991, Correlation of NW European Purbeck-Wealden (non-marine Lower Cretaceous) as seen in the English type-areas: Cretaceous Research 12, 511-26.

Arkell, W.J., 1935, The Portland beds of the Dorset mainland: Proceedings of the Geologists' Association 46, 301-347.

Arkell, W.J., 1953, Jurassic geology of the World: Oliver \& Boyd, London. 791pp.

Bralower, T.J., Ludvig, K.R., Obradovich, J.D., and Jones, D.L., 1990. Berriasian (Early Cretaceous) radiometric ages for the Grindstone Creek section, Sacramento Valley, California: Earth \& Planetary Science Letters 98, 62-73.

Brongniart, A.T., 1829, Tableau des terrains qui composent l'écorce du globe: Essai sur la structure de la partie connue de la Terre, Paris.

Casey, R., 1973, The ammonite succession at the Jurassic-Cretaceous boundary in eastern England. 193-266. In Rawson, P.F. and Casey, R. (Eds) The Boreal Lower Cretaceous: Geological Journal Sepcial Issue 5.

Channell, J.E.T. and Grandesso, P., 1987, A revised correlation of Mesozoic polarity chrons and calpionellid zones: Earth \& Planetary Science Letters $85,222-240$.

Detraz, H, and Mojon, P.Q., 1989, Evolution paleogeographique de la marge jurassiene de la Tethys du Tithonique-Portlandien au Valanginien: correlations biostratigraphique et sequentielle des facies marins et continentaux: Eclogae Geologicae Helveticae 82, 37-112.

Fitton, W.H.. 1836, Observations on some of the strata between the Chalk and the Oxford Oolite in the south-east of England: Transactions of the Geological Society London Ser. 2, 4, 103-388.

Galbrun, B., Rasplus, L., and Le Hegarat, G., 1986, Donnees nouvelles sur le stratotype du Berriasien: correlations entre magnetostratigraphie et biostratigraphie: Bulletin Societie geologique de France 2, 575-584

Gerasimov, P.A. and Mikhailov, N.P., 1966, The Volgian Stage and the international stratigraphical scale of the Upper Jurassic Series: Izv. Ac. Sci. USSR. Geol. 2, 118-138.

Grabowski, J., 2000, Palaeo- and rock magnetism of Mesozoic carbonate rocks in the sub-Tatric series (central West Carpathians)-palaeotectonic implications: Polish Geological Institute Special Paper 5, 1-88.

Grabowski, J. and Pszezolkowski, A., 2006, Magneto- and biostratigraphy of the Tithonian-Berriasian pelagic sediments in the Tatra Mountains (central Western Carpathians, Poland): sedimentary and rock magnetic changes at the Jurassic/Cretaceous boundary: Cretaceous Research 27, 398-417.

Grun, B. and Blau, J., 1997, New aspects of calpionellid biochronology: proposal for a revised calpionellid zonal and subzonal division: Revue de Paleobiologie 16, 197-214.

Guzhikov, A.Y. and Eremin, V.N., 1999, Regional magnetic zonality scheme for the Berriasian-lower Aptian from the North Caucasus. In CrasquinSoleau S. and De Wever P. (Eds). Peri-Tethys: stratigraphic correlations 3, Geodiversitas 21, 387-406.

Hoedemaeker, P.J., 1987, Correlation possibilities around the Jurassic/Cretaceous boundary. Scripta Geologica 84, 1-55.

Houša V., Krs, M., Krsova, M., Man, O., Pruner, P., and Venhodova, D., 1999, High resolution magnetostratigraphy and micropalaeontology across the $\mathrm{J} / \mathrm{K}$ boundary strata at Brodno, near Zilina, western Slovakia: summary of results: Cretaceous Research 20, 699-717.

Houš a V., Pruner, P., Zakharov, V.A., Kostak, M., Chadima, M., Rogov, M. A., Slechta, S., and Mazuch, M., 2007, Boreal-Tethyan Correlation of the Jurassic-Cretaceous Boundary Interval by Magneto- and Biostratigraphy: Stratigraphy and Geological Correlation. 15, 297-309.

Hunt, C.O., 2004, Palynostratigraphy of the classic Portland and Purbeck sequqnces of Dorset, southern England, and the correlation of Jurassic-
Cretaceous boundary beds in the Tethyan and Boreal realms. pp 173-186. In Beaudoin A.B. and Head, M.J. (Eds) The palynology and micropalaeontology of boundaries. Geological Society of London Special Publication 230.

Lowrie, W. and Channell, J.E.T., 1984, Magnetostratigraphy of the JurassicCretaceous boundary in the Maiolica Limestone (Umbria, Italy): Geology $12,44-47$.

Mazenot, G., 1939, Les Palaeohoplitidae tithoniques at Berriasiens du Sudest de la France: Mem. Soc. Geol. France 41, 1-303.

Michalík, J., Reháková, D., and Petercáková, M., 1990, On the stratigraphy of Jurassic-Cretaceous boundary beds in the Kysuca sequence of the West Carpathian Klippen belt, Brodno section near Zilina. Knihovna Zemního plynu a nafty, Hodonín, 9 b, 57-71.

Mitta, V.V., 2007, Ammonite assemblages from the basal layers of the Ryazanian Stage (lower Cretaceous) of central Russia: Stratigraphy and Geological Correlation 15, 193-205.

D'Orbigny, A., 1842-51, Paleontologie francaise. Terrains jurassique. Cephalopodes, Paris.

Ogg, J., Hasenyager, R.W., Wimbledon, W.A., Channell, J.E.T, and Bralower, T.J., 1991, Magnetostratigraphy of the Jurassic-Cretaceous boundary interval-Tethyan and English faunal realms: Cretaceous Research 12, 455-482.

Remane, J., 1971, Les calpionelles, Protozoaires planctoniques des mers mesogeeennes de 1Epoque Secondaires. Annales Guebhard 47, 1-25.

Remane, J., Borza, K., Nagy, I., Bakalova-Ivanova, D., Knauer, I., Pop, G., and Tardi-Folacz, E., 1970, Agreement on the subdivision of the standard calpionellid zones defined at the 2nd Planktonic Conference, Roma 1970 Acta Geologica Hungarica 29, 5-14.

Riding, J.B., Fedorova, V.A., and Ilyina, V.I., 1999, Jurassic and lowermost Cretaceous dinoflagellaye cyst biostratigraphy of the Russian Platform and Northern Siberia, Russia: Contributions of American Association of Stratigraphic Palynologists 36, 1-180.

Sey, I.I. and Kalacheva, E.D., 1997, The Jurassic-Cretaceous boundary in the Boreal Realm (biostratigraphy and Boreal-Tethyan correlation): Stratigraphy and geological correlation 5, 38-54.

Tavera, J.M., Aguado, R., Company, M. and Oloriz, F. 1994. Integrated biostratigraphy of the Durangites and Jacobi zones ( $\mathrm{J} / \mathrm{K}$ boundary) at the Puerto Escano section in southern Spain (province of Cordoba): Geobios Memoire Special 17, 469-476.

Wimbledon,W.A.P., 1983, The Portlandian, the terminal Jurassic stage in the Boreal Realm. Pp 534-549. In International Symposium on Jurassic Stratigraphy II. Geological Survey of Denmark, Copenhagen.

Wimbledon, W.A. and Cope, J.C.W., 1978, The ammonites faunas of the English Portland Beds and the zones of the Portlandian Stage: Journal of the Geological Society, London 135, 183-190.

Zakharov, V., Rogov, M., and Kiselev, D., 2006, The Volgian Stage and Jurassic/Cretaceous boundary in the Panboreal Superrealm. Abstract. In Proceedings of 7th International Congress on the Jurassic System, September 6-18, 2006, Kraków, Poland.

Bill Wimbledon graduated from University College Swansea 1971: PhD 1975. Research interests include biostratigraphy, the $\mathrm{J} / \mathrm{K}$ boundary interval, late Jurassic-early Cretaceous ammonites in U.K., France, Greenland, Ukraine and Russia, as well as non-marine: marine correlation and the Purbeck facies. Co-leader IGCP 506. Chairman of Berriasian/J-K Boundary WG of Cretaceous Subcommission 2006. Research Fellow at the University of Bristol, and Senior Geologist with the Countryside Council for Wales. Formerly Head of Geological Conservation Review Unit, Nature Conservancy Council. Secretary of ProGEO - the European Association for the Conservation of Geological Heritage.

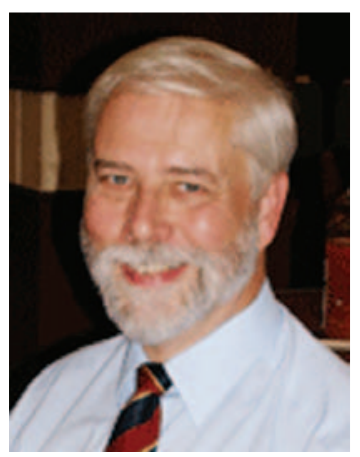

